\title{
Mother Images in Carol Ann Duffy’s Poetry
}

\author{
ZHOU Jie \\ Shandong University of Finance and Economics, Jinan, China
}

\begin{abstract}
"Mother” is sometimes associated with "other”. The same is true in some of Carol Ann Duffy's poems, in which some mothers are described as institutionalized in the patriarchal society and considered as "the other", losing self-identity. Duffy also describes women fighting against the patriarchal control generation after generation until they are finally free. Some mothers exhibit their own potentials as mothers, either able to or unable to fulfill the duties of both material and spiritual caretakers of the family.
\end{abstract}

Keywords: Carol Ann Duffy’s poems, mother, other, institutionalized, potentials

\section{Introduction}

Carol Ann Duffy (1955-), the first woman poet laureate appointed to the position in British history, owes both to the second-generation feminist in the 1970s and post-feminist poetics. She pays attention to women experience, to their sufferings and difficulties, including their identification as mothers. In her poems, some mothers are identified as institutionalized under male control to criticize the patriarchal control of motherhood, and some other mothers are with their own potentials to call on women's full play of their initiative to be care-taking and responsible mothers.

\section{Mothers Identified as Institutionalized Under Male Control}

In different cultures and historical period "most women perform the role of the mother in the institution of motherhood"(SHI, 2004, p. 28). As “a cultural construction”, motherhood is analyzed by Rich as an institution in patriarchy, a female experience shaped by male expectations by Rich. Women's mothering is thus defined and controlled by the patriarchal society, in which women live. The "patriarchal gaze" force women to obey the rules of mothering established by the dominant patriarchal culture. Women have no authority, nor perceptions, nor values of their own. Motherhood is not only imprisoned by patriarchy, but also turned into a form of oppression and exploitation, alienated from other women and from their bodies. "Woman's place is the inner space of the home; woman's anatomy lays on her an ethical imperative to be maternal in the sense of masochistic, patient, pacific; women without children are 'unfulfilled', 'barren', and empty women” (Rich, 1976, pp. 97-98). Women are deprived of the rights to choose whether to be or not to be a mother. They can not escape the trap of motherhood, and have to become victims of the institution of motherhood. Women have to sacrifice a lot, because all mothers are saintly in the religion of maternity. Behind the sanctity are women's loss of motherhood, the loss of the true nature of a woman's self, and the feeling of being wasted and fragile. Because institutionalized

ZHOU Jie, Ph.D., professor, School of Applied English Studies, Shandong University of Finance and Economics. 
motherhood causes pain and distorts women's lives, writers can create new and feminist possibilities in defining the experience of being a mother. So does Duffy, who wrote poems like “Whoever She Was”, “Recognition”, and "A Clear Note", etc., in which the mother is identified as institutionalized under male control.

As an example of a woman character whose identity is constructed upon her motherhood, the mother in the poem "Whoever She Was" from Standing Female Nude is considered as an "idealized mother", "A figure produced and then consumed for a 'shilling”", and "an object of exchange” (Kinnahan, 2004, p. 157). According to the poem, it seems that the mother's children have all grown up and left home, and the mother is left in confusion, unable to find her own identity as a mother and lost in who she is, just because of no children around her. She can only find fragments of memory and phrases.

In the first stanza of the poem, there are several images that describe the woman in a loss of self-identity. First, she is "a flickering figure/on a shilling screen. Not real" (Duffy, 1985, lines 1-2), of no importance or significance. Secondly, her "still wet" (Duffy, 1985, line 3) hands were associated with "sprout wooden pegs" (Duffy, 1985, line 3), stereotyped images for hard-working housewife. Thirdly, when she hung the washing out, she smelt "the apples / burning" (Duffy, 1985, lines 3-4), an image that shows that she has lost efficiency as a housewife. Besides images of vision and olfaction, the poet describes "little voices of the ghosts/of children on the telephone" (Duffy, 1985, line 5), calling "Mummy". The word "ghosts" shows that in the mother's mind the telephone call from her children sounds unreal. Obviously, the woman can only find her identity as a mother. After her children left her, she is left with fragments of memories of her life as a mother, and loss of self-identity. She can only identify herself with images of nursing and mothering, all traditional pictures of representative mother images.

Her memories are all about mothering and nursing. She remembers "The film is on a loop. Six silly ladies/torn in half by baby fists” (Duffy, 1985, lines 9-12), and herself bending over her children at night to kiss them. She remembers the perfume, the rustle of silk, and how she whispers "Sleep tight" to her children. She is wholly devoted to her role as a mother, and even "her maiden name sounds wrong” (Duffy, 1985, lines 16-17). She is unable to forget about her children, her duty, and role as a mother. She would keep the playroom and the photographs, turning the playroom over "on a clumsy tongue", and "making masks/from turnips in the candlelight./In case they come” (Duffy, 1985, lines 17-20).

The death of the woman's maternal existence, or the loss of her identity as a mother, is revealed by biblical metaphors in the following lines: "Whoever she was, forever their wide eyes watch her/as she shapes a church and steeple in the air" (Duffy, 1985, lines 21-22). And the use of "her" that seems to be causing confusion in the use of pronouns shows her confusion in finding herself. She is so trapped in motherhood that she feels as if her life has ended after her fulfillment of her maternal responsibility.

The mother is obviously identified as being house-bound, taking care of housework, because "the woman's role is that of housewife, mother, consumer of goods, and emotional support of men and children” (LIU, 2008, p. 38), but as her life is limited to cooking, nursing, cleaning, washing, and childcare, she knows nothing else. So in the end of the poem are two italicized lines: "You open your dead eyes to look in the mirror / which they are holding to your mouth" (Duffy, 1985, lines 27-28). After the children leave home, she seems to be "dead" and loses her identity. As pointed out by Rich, the home has become "a part of the world, a center of work, a subsistence unit” (LIU, 2008, p. 38), but "not a refuge, a place for pleasure and retreat from the cruelty of the 
'outside world'” (ibid). The woman always had to see to children's needs in the privatized home. She is so devoted to it that she not only developed complicated, subversive feelings but also a feeling of "desperate loneliness" (ibid), because she has no contact with other people.

A similar woman is described in "Recognition" from Selling Manhattan. This is a middle-aged woman who can only identify herself by devoting her life to housework and finally realize that her life as a housewife is a kind of waste. The poem contrasts the woman as a girl with a mother and wife, showing how a happy girl can lose her self-identity and turn into a dull housewife.

Her self-identity is found in her children, her husband and housework, but she finally identifies herself with the waste. The poet shows the change time has brought onto the woman's weight and face: she used to be lighter and her face was not swollen, but now she "put powder on, /but it flakes off” (Duffy, 1987, lines 8-9). She identifies herself in her relationship with her husband. She talks about her husband: "I love him/through habit, but the proof/has evaporated./He gets upset” (Duffy, 1987, lines 9-11), and tries her best to be qualified as a source of love and warmth and care for the family, or at least for her husband, who seems to be dissatisfied. She identifies herself as a housewife, whose duty includes shopping, when she tries "to do all the essentials/on one trip" (Duffy, 1987, lines 12-13). Obviously she has submitted herself to the role of a housewife, and has developed a habit of buying all the essentials once to save time. In doing so, she realizes how foolish it is, and she is in sadness in the past beautiful memory. She weeps as she sees "creamy ladies held a pose" (Duffy, 1987, line 20) in the window, because she is left "clogged and old” (Duffy, 1987, line 21). Finally she identified herself as "The waste” (Duffy, 1987, line 22), almost forgets her purse and fumbled, making the shop girl gape at her coldly.

The poem ends with a description of confusion, showing the woman failing to recognize herself when shopping, which is also a failure or a loss of self-identity.

\section{Three Generations Against the Trap}

Three women in different generations of a family are described in "A Clear Note" from Standing Female Nude. This is a long poem with 144 lines, in three parts, each of which contains the dramatic monologue of a respective woman from three generations of one family. Both the grandmother Agatha and the mother Moll have experienced unfulfilled lives because of the trap of the patriarchal society and marriage as institutionalized. And both advise their daughters try not to be trapped in motherhood but to develop their own potentials.

Agatha, of the first generation, emigrated from Ireland to Scotland, is identified as a nurse for eight children, "tending the dying./Four kids to each breast” (Duffy, 1985, Canto1, line 2). For her whole life, she hopes for "the fields of Ireland only/and a man to delight” (Duffy, 1985, Canto 1, lines 9-10), but all she can get is "a move across the water/to Glasgow and long years of loathing / with the devil she has married” (Duffy, 1985, Canto 1, lines 14-16). This is a typical woman that is born in the early twentieth century, devoted to her role as a mother and wife, with a dissatisfying husband, because he would "kiss me goodnight - me weeping in my bed", or "turn away cold, back rigid,/but come home from work and take me on the floor / with his boots on and his blue eyes shut" (Duffy, 1985, Canto 1, lines 5-8). With this loveless husband and her own dreams unfulfilled, her heart is broken: "Again and again throwing life from my loins / like a spider with enough rope / spinning and wringing its neck. And he / wouldn't so much as hold me after the act” (Duffy, 1985, Canto 1, lines 17-20). The "love" life between the wife and husband is brutal and mechanical, and she gives births like a spider spinning and wringing 
its neck, trapped. Thinking that "it won't be over till one of us is dead” (Duffy, 1985, Canto 1, line 21), she feels frustrated because her dreams as a woman has been suppressed by her husband. Her only hope is "Don't bury him on top of me. Please./I had a voice once, but it’s broken” (Duffy, 1985, Canto 1, lines 23-24). But unfortunately he is buried on top of her finally, making her afterlife still oppressed by him. Her revolt against her husband can only be expressed with insulting words, such as "scunner", "the devil”, "a corpse”, and "that bastard”, etc.

Moll, of the second generation, is a daughter of Agatha's, born in the mid twentieth century. She is in need of convincing herself of her identity. Her husband is not as brutal as her father is, but he does not want her to work, even though the "job pays well, but more than that,/there's the freedom. Your father's against it” (Duffy, 1985, Canto 2, lines 9-10). She wants to go out to work, and "fly to stay with you alone”, so she tells Bernadette, the only daughter among her five children, about the fights between her and her husband, because he "broods on what I'd get up to / given half the chance. Men!” (Duffy, 1985, Canto 2, lines 33-36) The word “Men!” is obviously with hatred for men. Moll is imprisoned by the traditional idea of the responsibility of a housewife within the house, unable to go out to work. Patrick Jenkin in 1979 frankly denied women of the same right as men to work, which shows the traditional idea of women not at work from the nineteenth century and that of the Thatcherite family (Kinnahan, 2004). Moll advises her daughter not to give birth to babies but give birth to her own life, which she had failed to do so herself, because she's trapped by her four sons and her husband "like gold leaf", and her, "with a black hole of resources” (Duffy, 1985, Canto 2, lines 37-40). Unlike Agatha, Moll is able to talk about her sexual desires with her daughter. Besides complaints, she is also able to talk about women's liberation. She tries to change the feminine image by wearing men's cap. Having had the chance to work out of the house, she is surely one of the generation having benefited from the first wave feminist movement. But because of the patriarchal system, she is still trapped in the family.

Bernadette, the third generation, having known how Agatha and Moll end their lives unfulfilled because they have been unable to "swim in impossible seas/under the moon" (Duffy, 1985, Canto 2, lines 46-47), is able to identify herself. She has kept in mind the sadness and hardship of the older generation's lives, "The hopes of your thousand mothers/sing with a clear note inside you/Away, while you can, and travel the world” (Duffy, 1985, Canto 2, lines 26-28), and she kept her mother's words about giving birth to her own life. So she swims "with ease in all /possible seas" (Duffy, 1985, Canto 2, lines 33-34). Her mother's dream to swim in impossible seas is realized in the daughter's life. As the third generation of the family, she has successfully liberated herself from traditional women's role and finds her own identity as an independent and free woman.

\section{Mothers Identified as With Their Own Potentials}

Besides criticizing the patriarchal system that destroys women's lives by institutionalizing motherhood and showing women's hardship in their fight for liberation and freedom, Duffy also wrote poems to identify women as being able to, or having failed to, develop their potentials or fulfill their duties as mothers.

The mother bears the weight of Eve's transgression (is, thus, the first offender, the polluted on, the polluter) yet precisely because of this she is expected to carry the burden of male salvation. Lest she fall, there are horrible examples to warn her. (LIU, 2008, p. 31)

\section{Horrible Examples}

One horrible example Duffy gives is the mother of Byron, who is said to have laid the foundation of her 
son's preeminence in guilt. It is thought that for the crimes of the poet Lord Byron, his mother deserves the curse, because she has fostered those passions in his youthful heart. In Duffy's poems, mothers like Byron's mother lay foundations of their children's preeminence in guilt, as shown in the poem "Psychopath", or lay foundations of her child's preeminence in tragedy, as shown in the poem "Girl Talking", or neglect their child in their growth, or lay foundations of her child's preeminence in language use, as in the poem "The Way My Mother speaks", or the mother is not only a material housekeeper, but also a spiritual housekeeper, as in such poems as "Litany" or "Mouth, with Soap". All of these poems show the importance of a mother to her child or children, showing mothers identified with potential to influence their children.

In the poem "Psychopath" from Selling Manhattan, there is a mother like the mother of Byron's. This is proved by the psychopath's memory and words, after he kills the girl, "Mama, straight up. I hope you rot in hell" (Duffy, 1987, line 41), which shows his hatred for his mother who has done that shameful thing. He remembers the old man who "sloped off, sharpish. I saw her through the kitchen window”(Duffy, 1987, line 42). In his memory, "the sky slammed down on" his school cap, and his sandwiches "were near her thigh, then the Rent Man / lift her cigarette” and he "ran, ran...” (Duffy, 1987, lines 43-46). Obviously, the little boy is influenced by his mother's adultery, which led him to a woman at age 12 and turned him into a psychopath, and finally he committed such crimes as rapes and killing. Another example is the mother in the poem "Model Village" from Selling Manhattan. The speaker, Miss Maiden, poisoned her mother, because of a lover waiting for her for years, but rejected by her mother. So when the man didn’t come back, Miss Maiden, faced with her mother's lips of reproach, got the idea of poisoning her. The mother turns out to be an obstacle for Miss Maiden's love, or marriage, and led to the daughter's hatred and crime.

Therefore, mothers are responsible for their children's growth. But they are unable to offer help to their children when they are confined by the patriarchal system. In "Girl Talking” from Standing Female Nude, the mother is just as passive as her daughter, after whose death, she can only "held her down" and "cried". The mother has been too obedient to men and the patriarchal society to have her own thoughts. In some way, her ignorance and obedience partly led to her daughter's tragedy. Similar mothers are described In "Comprehensive" from Standing Female Nude, when the fourth speaker feels bored, and says that "My mum is bad with her nerves. She won't/let me do nothing" (Duffy, 1985, lines 26-27), which proves that the mother is not only being of no help to her child, but also might have been cause of the child's boredom. In "Lizzie, Six" and "Education for Leisure" from Standing Female Nude, children are neglected or ignored, with no description of mother at all.

\section{Mothers as Moral and Spiritual Guide}

According to Kinnahan, there is an "interdependence" of the mother's role as a consumer and the role as a moral, spiritual guide, and

The interdependence of one role upon the other in the traditional family results, as in the poem, from an inter-splicing of discourses of the maternal, but one that must be policed through strict boundaries to keep out resistant or disruptive discourse. The conversation is contained within the boundaries established by their roles as caretakers of the material and spiritual needs of the family, although clearly their own spiritual needs are unattended (Kinnahan, 2004, pp.158-159).

In the poem "Litany" from Mean Time, the mother is identified as a moral, spiritual guide for her children. The poet gave the reader the consumer image of married women in the poem by description of the wives' 
“stiff-hair”, “red smiles”(Duffy, 1993, line 3), “Mrs. Barr’s American Tan leg”(Duffy, 1993, line 5), “cellophane”(Duffy, 1993, line 7), “polyester shirts”(Duffy, 1993, line 8), “bright stones in engagement rings”(Duffy, 1993, line 10), and “sharp hands poised over biscuits”(Duffy, 1993, line 11), etc. And the girl describes their marriages as “terrible” (Duffy, 1993, line 7), and mentions “the code I learnt at my mother's knee, / pretending to read” (Duffy, 1993, lines 14-15), related to the spiritual life. Because she said “A boy in the playground...told me / to fuck off” (Duffy, 1993, lines 19-20), her mother came into “uproar” (Duffy, 1993, line 22), made her to apologize, to say “sorry” to “Mrs. Barr, Mrs. Hunt, Mrs. Emery” and “Mrs. Raine”, which shows her mother's moral authority to wash her daughter's mouth with soap.

Mothers can be of great help for their children. For example, in "Comprehensive” from Standing Female Nude, finding the children's nostalgia, the first speaker's mother tries to comfort them by saying that they will get their own house in England so that they won’t miss their hometown Africa so much. In "Who Loves You” from The Other Country, the speaking mother expresses her worry about the children's "travelling in those mystical machines” (Duffy, 1990, line 1), warns them of people falling from the clouds, getting burned in public places, being gnawed to shreds, or ending their lives in the shortcut. She also suggests them to "breathe in and out" (Duffy, 1990, line 3) easy, to "rest where the cool trees drop to a gentle shade” (Duffy, 1990, line 7), to "send me your voice” (Duffy, 1990, line 11), and to "walk in the light, steadily hurry towards me” (Duffy, 1990, line 15). She repeated "Safety, safely, safe home” (Duffy, 1990, lines 4, 8, 12, 15, 16) in the last line of each of the four stanzas to show her worries for her child's safety and her love and care for them. In “The Way My Mother Speaks" from The Other Country, the mother is shown as of influence on the child's use of language. She says her mother's phrases to herself in her head when she feels homesick. The speaker repeats the mother's phrases like “The day and ever" (Duffy, 1990, lines 5, 20, 21) and "What like is it” (Duffy, 1990, lines 11, 14) “for miles", because she is "homesick, free, in love / with the way my mother speaks".

Daisy Goodwin thinks that Duffy’s poem “The Way My Mother Speaks” shows Carol Ann Duffy’s mother as “the force behind Carol Ann’s decision to become a poet”. In her article "Carol Ann Duffy: The original good line girl”" on The Sunday Times, May 3, 2009, Daisy Goodwin introduces Duffy’s mother, May, as “the first reader of her poems" 2 from the very beginning. Duffy says, if her mother found her poetry too complex, she would ask her what they meant and that made Duffy realize the "importance of saying difficult things in simple language”3. She considers her mother's "Irish syntax and voice music”4 as what started her love of words, and she "inherited from her mother a passion for language". 5

\section{Conclusion}

Just as Cixous connects the idea of "mother" with the idea of "other", and occasionally discusses the relationship between "mother” and “other” and occasionally talks about woman as “other” (Blyth \& Susan, 2004, pp. 22-23), Duffy has written about mothers' lives both as institutionalized and of self potentials. She shows that institutionalized mothers in the patriarchal society are considered as "the other" by the society, thus losing

\footnotetext{
1 See from http://entertainment.timesonline.co.uk/tol/arts_and_entertainment/books/article6210786.ece

2 See from http://entertainment.timesonline.co.uk/tol/arts_and_entertainment/books/article6210786.ece

3 See from http://entertainment.timesonline.co.uk/tol/arts_and_entertainment/books/article6210786.ece

4 See from http://entertainment.timesonline.co.uk/tol/arts_and_entertainment/books/article6210786.ece

5 See from http://entertainment.timesonline.co.uk/tol/arts_and_entertainment/books/article6210786.ece
} 
self-identity and their potentials. But mothers with their own potentials are different, with some being able to fulfill the duties of both material and spiritual caretakers of the family, but some being a failure for various reasons.

\section{References}

Abbott, J. S. (1833). The mother at home, or the principles of maternal duty. New York: American Tract Society.

Blyth, I., \& Susan, S. (2004). Hélène Cixous: Live theory. London \& New York: Continuum International Publishing Group.

Chodorow, N. (1978). The reproduction of mothering: Psychoanalysis and the sociology of gender. CA: University of California Press.

Cixous, H. (1986). Sorties: Out and out. In H. Cixous \& C. Clement (Eds.), The Newly Born Women (pp. 63-132). Minneapolis: University of Minnesota Press.

Duffy, C. A. (1985). Standing female nude. London: Anvil.

Duffy, C. A. (1987). Selling Manhattan. London: Anvil.

Duffy, C. A. (1990). The other country. London: Anvil.

Duffy, C. A. (1999). The world's wife. London: Picador.

Goodwin, D. (2009, May 3). Carol Ann Duffy: The Original Good Line Girl. The Sunday Times. Retrieved from http://entertainment.timesonline.co.uk/tol/arts_and_entertainment/books/article6210786.ece

Kinnahan, L. A. (2004). Lyric interventions: Feminism, experimental poetry, and contemporary discourse. Iowa City: University Of Iowa Press.

LIU, Y. (2008). A theoretical reader in motherhood. Wuhan: Wuhan University Press.

Rich, A. (1976). Of woman born: Motherhood as experience and institution. New York: W. W. Norton.

SHI, P. P.(2004). Mother-daughter relationship \& the politics of sex and race. Kaifeng: Henan University Press. 